\title{
Research
}

\section{Quantifying the Human Appropriation of Fresh Water by African Agriculture}

\author{
$\underline{\text { Martina Wei }}^{1}, \underline{\text { Rüdiger Schaldach }}^{1}, \underline{\text { Joseph Alcamo }}^{1}$, and Martina Flörke $^{1}$
}

\begin{abstract}
Human appropriation of renewable freshwater (HARF) is a measure for the influence of human activities on the global water cycle. It describes the fraction of accessible water that is directly used by human-dominated systems. We present a comprehensive model-based analysis of HARF for crop production on the African continent. Our analysis includes the components evapotranspiration from cropland ("green" water fluxes) and water used for cropland irrigation (crop-related fraction of "blue" water fluxes). Model experiments were conducted for two scenarios with a time horizon of 2050, taking into account the combined effects of land-use change, climate change, and technological change. For the year 2000, evapotranspiration from Africa's rainfed cropland (green water flux) is estimated to be 1085 $\mathrm{km}^{3} / \mathrm{yr}$, whereas the abstraction of water for irrigation purposes from the renewable water resources (blue water flux) is estimated to be approximately $180 \mathrm{~km}^{3} / \mathrm{yr}$. According to the model experiments, between 2000-2050, an area between 1.25 million $\mathrm{km}^{2}$ and 1.56 million $\mathrm{km}^{2}$ of natural biomes will be converted to cropland. Consequently, for 2050, evapotranspiration from rainfed cropland is substantially greater than in 2000 , ranging from $1870-2040 \mathrm{~km}^{3} / \mathrm{yr}$, depending on the scenario, and irrigation abstraction increases up to $194-330 \mathrm{~km}^{3} / \mathrm{yr}$. These findings point out the significant role of water appropriated for rainfed crop production in the continental water cycle, in contrast to the sum of water appropriated for irrigation. Furthermore, they suggest that it would be worthwhile to look for opportunities to reduce the amount of water evaporated and transpired from cropland to increase the "water productivity" of cropland. Finally, they indicate that under the given scenarios, this additional production is very likely to come at the cost of the extent of natural biomes and their associated ecosystem services.
\end{abstract}

Key Words: Africa; agriculture; blue water; green water; hydrological modeling; LandSHIFT; land-use modeling; WaterGAP

\section{INTRODUCTION}

According to recent scenarios, Africa is expected to face further expansions of cropland to fulfill the food demand of a growing human population (Alcamo et al. 2005, Rothman et al. 2007). The impact of this development, together with climate change and technological innovation, is likely to significantly affect the continental water cycle, and therefore, the amount of water available to support society and ecosystems. To develop a clearer understanding of the complex interactions between land and water and the impact of anthropogenic interference on the continental and regional scale, we apply the concept of "human appropriation of renewable freshwater" (HARF). HARF describes the fraction of accessible fresh water that is directly used by human-dominated systems (Postel et al. 1996).

On the African continent, rainfed cropland makes up most of the cultivated area $(96.5 \%$ in sub-Saharan Africa). Irrigation plays a prominent role in northern African countries, with irrigation water uses in the range of $82 \%-85 \%$ of total water withdrawals (Rockström et al. 1999, Alcamo et al. 2007). For a comprehensive quantification of HARF, we apply the concept of "blue" and "green" water fluxes. This concept includes not only the fraction of horizontal flow, i.e., surface and subsurface runoff, and 
renewable groundwater eventually accumulating as river discharge, but also the fraction of vertical flow, i.e., evapotranspiration (Falkenmark 1995, Rockström 1999).

Recent studies have estimated current green water fluxes from world agriculture at $5000-7200 \mathrm{~km}^{3} / \mathrm{yr}$, blue water use in irrigated agriculture at approximately $1600 \mathrm{~km}^{3} / \mathrm{yr}$, and green water fluxes from grazing lands at $8000-12000 \mathrm{~km}^{3} / \mathrm{yr}$ (Rockström et al. 2007, 2009). It is expected that changes in land use and climate will exert a strong influence over regional water balances and hence over green and blue water fluxes. In the past, for example, deforestation has decreased local evapotranspiration and increased surface runoff (Douglas et al. 2005). The expansion of irrigated areas, on the other hand, has increased evapotranspiration at the expense of the total water available for society's use. It has also led to increased surface runoff when applied lavishly (Rockström et al. 1999, Scanlon et al. 2007). Up until now, few estimates have been made about finer scales. Work has concentrated on questions related to water availability under current climate and socioeconomic conditions (Schuol et al. 2008).

The key question of the model-based analysis presented here is how HARF by cropland will develop during the next decades in Africa, in terms of possible changes in climate, land use, and access to modern irrigation technology. To answer this question, we link two spatially explicit simulation models for hydrology (WaterGAP) and land-use change (Land Simulation to Harmonize and Integrate Freshwater Availability and the Terrestrial Environment (LandSHIFT)) to systematically calculate the green and blue water fluxes of African agriculture on continental and country scales.

As a first step, we analyze the current conditions (based on the year 2000). We then conduct model experiments for two scenarios with a time horizon of 2050, taking into account the combined effect of changes in food production and the resulting landuse change, climate change, and technological change on green and blue water fluxes. Estimates of future climate and driving forces of land-use change up to 2050 are taken from the "Policy First" and "Security First" scenarios of the UNEP Global Environmental Outlook-4 Report (GEO-4) (Rothman et al. 2007). The main focus of our work is to give a continental overview of potential future developments. The outcome of all of the simulation experiments is therefore analyzed at a continental level. In addition, in order to give a more detailed overview and to establish links to political units, we analyze the calculated green and blue water fluxes on a country basis.

\section{METHODS}

\section{Blue and Green Water}

For our purposes, green water fluxes on cultivated areas are defined as evapotranspiration (i.e., the sum of water evaporated from the unsaturated soil layer plus that transpired by plants) because this is the amount of water used for crop growth. To compare green water fluxes on cultivated land with green water from natural vegetation (i.e., the fluxes that were present before this land was converted to cropland), we define green water as the sum of evapotranspiration plus interception. These fluxes make up the theoretically available amount of water to support biomass production in that area.

Blue water required for agricultural production is defined as the amount of water withdrawn for irrigating crops, including conveyance and other losses occurring on the way to, or in the vicinity of, crops. It constitutes the amount of water society has to provide to an area that would otherwise not be suitable for crop production due to a water-limited climate. Most of this water is converted into green water by consumption. Access water is returned and available for reuse.

Consequently, HARF for crop production is described by the amount of water used in the evapotranspiration process, which is provided by precipitation and irrigation plus the water losses through the irrigation system.

\section{Scenario Analysis}

Scenarios are plausible descriptions of how the future may unfold (Alcamo 2008). They are used by the scientific community as a research tool for estimating and assessing possible future states of the environment or for examining the effect of alternative policy options. They are based on coherent and consistent sets of assumptions about key driving forces and relationships (storylines). 
This qualitative description of driving forces is then translated into a quantitative description during the scenario analysis, on the one hand involving close dialog with experts, policy makers, and stakeholders, and on the other hand with model computations. With the key objective of exploring alternative future developments, the storylines are most often characterized by two opposite drivingforce pathways, e.g., globalization of markets vs. regionalization (Alcamo 2008). The scenarios chosen for this study were developed for the fourth Global Environment Outlook: Environment for Development (GEO-4) assessment (United Nations Environment Programme 2007). For a description of storylines, please refer to the section below entitled "Scenario Data."

\section{Land-Use Change Model}

LandSHIFT is a spatially explicit dynamic model that simulates land-use change on the continental and global scales. The model has been tested in case studies for India and Africa (Alcamo and Schaldach 2006, Schaldach et al. 2006, Schaldach et al. 2009). Driving variables are provided as input data on the country level and include the amount of crop production, and the increase in crop yields due to technological change and population growth. In our analysis, these input data are calculated by other models, as described in the "Scenario Data" section below. The output of LandSHIFT consists of landuse and land-cover grid maps with a cell size of 5 arc min and a set of country-level indicators (e.g., area statistics for land-use types and irrigated cropland). The model distinguishes among 14 landuse types. Each grid cell has one dominant land-use type and a fraction that is used for settlement area (i.e., that is not available for the dominant type of land use). The land-use type "arable land" is further subdivided into nine crops types.

LandSHIFT couples two modules to represent human and environment components of the global land-use system and their linkages. The "productivity module" calculates potential crop yields under rainfed and irrigated conditions for each grid cell. This information is used by the LandUse Change (LUC) module (see below) to evaluate each cell's suitability for agricultural activities, and to determine the amount of crop production that can be allocated there. Major inputs to the module are global-yield maps calculated with a grid version of the ecosystem model DAYCENT (Parton et al. 1998, Stehfest et al. 2007). Rainfed crop yields are adjusted upward to take into account technological improvements over time, and the percent of crop area that is irrigated.

The LUC module simulates land-use change and the underlying human decision-making processes. The main function of this module is to regionalize the country-level input for crop production and settlement area (based on population growth) to the grid level. In our analysis, these calculations are carried out in two steps by two submodules: METRO for settlement area and AGRO for cropland. LandSHIFT assumes that settlement area has higher priority and, therefore, is allocated first (i.e., it can displace existing cropland). In the first step, the suitability of each grid cell for settlement and cropland is determined by a multi-criteria analysis (Eastman et al. 1995). Here, landscape features such as potential crop yields and terrain slope, as well as spatial neighborhood relations and socioeconomic factors (e.g., population density and road infrastructure), are evaluated by a weighted linear combination. Additionally, land-use constraints prevent the conversion of grid cells that are located within nature reserves to settlement or cropland. In the next step, crop production and land requirements for settlement are spatially allocated to the grid cells. The METRO submodule uses a rule-based approach to calculate changes in settlement area due to population growth. The spatial allocation of crop production (AGRO) is calculated with a modified version of the multi-objective land allocation algorithm (Eastman et al. 1995).

\section{Hydrological Model}

With a spatial resolution of 30 arc min, the WaterGAP model (Alcamo et al. 2003, Döll et al. 2003) calculates current and future water availability by simulating the continental water cycle, taking into account precipitation, snowmelt, interception, evaporation, soil water, groundwater storage, and runoff. Surface and subsurface flows are routed through river basins using a directionalflow scheme (Döll and Lehner 2002). Current and future water withdrawals and consumptions are calculated for the industrial, domestic, and agricultural sectors. The water consumption is abstracted from the natural flow. The remainder forms river discharge. The simulated river discharge 
is tested against a measured time series provided by the Global Runoff Data Center (GRDC 2004). The WaterGAP model is very well suited for scenario analysis as climate and social-economic drivers can be adapted to scenario conditions. It has previously been applied to a number of scenario studies, including Global Environment Outlook 3 (GEO-3), Global Environment Outlook 4 (GEO-4), Millennium Ecosystem Assessment (MEA), and Dialogue on Water and Climate (WATCLIM) (UNEP 2002, 2007, Alcamo et al. 2005, 2007, Carpenter et al. 2005).

We use the WaterGAP model to calculate green water fluxes from the daily vertical water balance in each grid cell. Following Priestley and Taylor's (1972) radiation-based calculation of potential evapotranspiration, actual evapotranspiration is derived from canopy and soil water balances. The level of crown moisture saturation determines the fraction of incoming precipitation that directly evaporates without reaching the soil, whereby the maximum canopy storage is calculated as a function of the leaf-area index. The remainder accumulates actual soil moisture until saturation. The maximum soil water capacity results from the depth of the effective root zone and specific water capacity of the particular soil. Excess water is routed to the adjacent grid cell (Alcamo et al. 2003).

Blue water fluxes on cropland are calculated using WaterGAP's irrigation module (Döll and Siebert 2002) as a function of climate, extent of irrigated area (Döll and Siebert 2000), cropping intensity, and crop type with a 30 arc min grid-cell resolution. Evapotranspiration is crop specific and depends on the growing stage of the crop. Due to data constraints, the model currently distinguishes rice and non-rice crops. The irrigation requirements are determined in three steps. First, cropping patterns and optimal growing seasons are determined based on soil suitability and climate, taking into account multi-cropping if applicable. Next, water consumption of irrigated crops is calculated for each day of the growing season. Water withdrawals for irrigation (blue water fluxes) are calculated by dividing plant water requirements by irrigation project efficiencies, accounting for waterdistribution losses through seepage and evaporation (Döll and Siebert 2002, Alcamo et al. 2003). Irrigation project efficiency follows estimates from the Food and Agriculture Organization (FAO 1997) for 84 regions in Africa. Validation of the model with independent data shows a good agreement for modeled irrigation-water demand (Döll and Siebert 2002). For scenario simulations, climate, extent of irrigated area, crop type, and project efficiency are adjusted to scenario conditions.

To take into account interannual climate variability, WaterGAP calculates both green and blue water fluxes on a monthly basis for a 30 -yr period. Here, we only report the long-term average annual result for the 30-yr period. For the baseline model experiment (see below), this period is 1971-2000. For model experiments concerning conditions in 2050, we scale data from the 1971-2000 period with climate-change data to create an artificial future 30yr period. This is explained in the "Scenario Data" section, below.

\section{Model Coupling}

Green and blue water fluxes are calculated by softlinking the WaterGAP and LandSHIFT models (i. e., the models are run in a sequential order). LandSHIFT uses country-scale input information on agricultural production and changing crop yields as specified in the GEO-4 scenarios. Based on this information, the model calculates changing rainfed and irrigated cropland area between 2000-2050. For the expansion of irrigated area, it is assumed that the fraction of irrigated land for each crop type remains constant at year 2000 levels. If, for example, in a particular country, $20 \%$ of a 1000 -ha maize area is irrigated in 2000 and the scenario assumes a doubling of maize area by 2050, this will automatically lead to an expansion of irrigated area from 200-400 ha. For rice, it is assumed that the total area is irrigated.

The resulting grid maps serve as inputs into the water-flux calculations of WaterGAP. Green water fluxes are computed by WaterGAP for grid cells designated as "cropland" in LandSHIFT. Every WaterGAP run uses a representative land-use or land-cover map (i.e., for 2000 or 2050) calculated with LandSHIFT, aggregated to the grid-cell resolution of WaterGAP of 30 arc minutes. Results are presented in this resolution.

To give a more realistic spatial picture of blue water fluxes, the changes of irrigated area calculated by LandSHIFT are summed up for each country level and then redistributed by WaterGAP to the grid cells 
that are suitable for irrigation. Factors determining this suitability comprise information on area equipped for irrigation (Döll and Siebert 2000) and climate. In the scenario runs, the irrigation project efficiency is adjusted to take into account technological improvements or deterioration over time, consistent with the underlying scenario assumptions (see "Scenario Data" section).

\section{SIMULATION EXPERIMENTS}

\section{Underlying Assumptions}

Four simulation experiments are conducted by running the two models to assess the impact of different components on green and blue water fluxes. These components include climate, land-use change, and access to technological progress in terms of crop-yield increases (given in metric tons per ha) and irrigation field efficiencies represented in a way that advanced irrigation technologies will result in lower water distribution losses. The change of cropland area is primarily driven by changes in the amount of crop production and increases in crop yields.

- Model experiment 1 (Baseline 2000): Calculates blue and green water fluxes for a reference climate period (1971-2000). Information on climate, cropland area, and level of technology is based on year 2000 data.

- Model experiment 2 (Climate change 2050): Takes into account only the impact of climate change on green and blue water fluxes. Cropland area and irrigation project efficiency are set to year 2000 values.

- Model experiment 3 (Climate change, landuse change, and technological change 2050): Takes into account the combined effects of changing climate, changing cropland area, and changing irrigation project efficiency on green and blue water fluxes.

- Model experiment 4 (Natural vegetation green water fluxes): Calculates future green water fluxes under climate change in the area that is converted to cropland from 20002050 , assuming that the area is still covered by the type of natural vegetation present before the conversion. This run provides a reference point for determining whether the expansion of cropland results in an increase or decrease of green water fluxes on the converted land.

Model experiments 2-4 apply to future conditions, and were performed for two scenarios from the set of scenarios recently developed as part of the Fourth Global Environmental Outlook Report (GEO-4) by UNEP (Rothman et al. 2007). We have selected these scenarios because they provide a consistent and, even more importantly, alternative set of socioeconomic assumptions for the year 2050 that allow us to explore a large range of future developments.

\section{Data for the Baseline Period}

The initial land-use map used by LandSHIFT for 1992 is based on the International GeosphereBiosphere Programme (IGBP) global land-cover data set (Loveland et al. 2000), derived from Advanced Very High Resolution Radiometer (AVHRR) source-imagery data. Additional information on the spatial distribution of crop types is generated by a procedure that merges land-cover data with subnational census data (Heistermann et al. 2006). This map also comprises information on the share of irrigated area for each crop type at the country level.

The LandSHIFT routines for suitability assessment and for land allocation use grid-level information on landscape characteristics, zoning regulation, and land-use related model variables. Population density is derived from the Global Rural-Urban Mapping Project (GRUMP) alpha development data (CIESIN 2004), whereas slope data is based on the HYDRO1k data set (USGS 1998). The river network density is calculated by the line density of rivers per grid cell, based on the HYDRO1k data set on streams (U.S. Geological Survey 1998). The information on infrastructure is assessed through the Vector Map Level 0 (VMPA0) data set on roads (National Image and Mapping Agency 1997). To derive information about zoning regulation, we map the grid cells to data sets on areas designated as national or international conservation areas (World Database on Protected Areas Consortium 2004).

The year 2000 land-use map that we use as a baseline in our analysis is calculated by the LandSHIFT model based on these initial map and census input 
data for population and crop production (FAO 2008) for the year 2000 (Schaldach and Alcamo 2006). Climate data for the reference period 1971-2000 are taken from the CRU TS 2.1 gridded data set for monthly precipitation, air temperature, cloud cover, and frequency of wet days (Mitchell and Jones 2005).

\section{Scenario Data}

Estimates of future climate and driving forces for land-use change up to 2050 for the experiments 24 are derived from the "Policy First" and "Security First" scenarios of UNEP's GEO-4. (Rothman et al. 2007). The storyline of the "Policy First" scenario describes a world where governments implement strong policies to protect the environment and increase human well-being while promoting economic growth through a high level of international cooperation. However, the attempt to achieve both economic growth and environmental protection is only partially successful because high population growth, increasing industrial activity, and growing energy consumption cannot be completely covered by renewable energy and other resources.

In contrast, the "Security First" scenario describes a world where natural and regional interests are turned inward, resulting in a relatively low level of international cooperation. Governments' interests center on regional security, including resources. Sustainable development is only an instrument to increase access to, and use of, the environment. The diffusion of technology and information is low and trade barriers limit the movement of goods across borders. Governments lose power as private interests increasingly influence decisions. International climate policy is undeveloped and ineffective. The quantitative interpretation of these storylines is described in detail by Rothman et al. (2007). For our analysis, we use quantitative-scenario drivers for climate, demography, economy, agricultural production and yields, and technological change regarding crop-yield changes and irrigation project efficiency. In the following paragraphs we briefly review these scenario drivers.

Climate data for 2050 for the "Policy First" and "Security First" scenarios were derived by scaling the reference period's (1971-2000) monthly temperature and precipitation with the differences between the years 2000-2050, calculated by the IMAGE 2.4 model (Bouwman et al. 2006). The climate-model component of IMAGE 2.4 is often used in integrated assessments and combines a relatively simple energy-balance approach with a consistent scheme for downscaling changes in surface temperature and precipitation to a global grid based on results from more complex dynamic global-climate models (Bouwman et al. 2006).

The climate data generated by IMAGE 2.4 for Africa from the present to 2050 shows only minor differences between the two scenarios because their emission pathways do not lead to significantly different atmospheric greenhouse-gas concentrations up to the middle of the $21^{\text {st }}$ century. The continental average surface-temperature increase up to 2050 for Africa (relative to the pre-industrial level) for both scenarios is approximately $2^{\circ} \mathrm{C}$. The highest temperature increases (approximately $3^{\circ} \mathrm{C}$ under "Security First" and $2.5^{\circ} \mathrm{C}$ under "Policy First") occur over the northwestern and southern parts of Africa. Long-term annual mean precipitation increases by about $10 \%$ over most of the continent. Precipitation decreases by approximately $15 \%-$ $20 \%$ in small areas of western and southern Africa and the coastline of northern Africa. In general, the climate projections are consistent with those from the fourth assessment report of the Intergovernmental Panel on Climate Change (Solomon et al. 2007).

Demographic change and gross domestic products (GDP) for the GEO-4 scenarios have been calculated by the International Futures model (Hughes and Hillebrand 2006). Total population in Africa in the year 2000 was 795 million. In the "Policy First" scenario, population increases to 1660 million in 2050, while average national income increases from U.S.\$702 to more than U.S. $\$ 4100$. Under the "Security First" scenario, we find a population increase of up to 2270 million, with GDP only increasing by up to U.S.\$1597.

Crop production is calculated by the International Model for Policy Analysis of Agricultural Commodities and Trade (IMPACT) (Rosegrant et al. 2002). Under the "Policy First" scenario, production of the major crop types (wheat, maize, other grains, soybeans, millet, and sorghum) increases from 77 million metric tons in 2000 to 272 million metric tons by 2050 . Along with this, per capita food availability increases to a level comparable with European standards in 2000 
Table 1. Land-use data for the baseline and scenario calculations.

\begin{tabular}{llll}
\hline \hline Area $\left[1000 \mathrm{~km}^{2}\right]$ & 2000 & 2050 & 2050 \\
& & Policy First & Security First \\
\hline Total cropland & 2292 & $3543(+55 \%)$ & $3808(+66 \%)$ \\
Rainfed cropland & 2056.572 & $3324.126(+62 \%)$ & $3478.394(+69 \%)$ \\
Irrigated cropland & 235.428 & $308.874(+31 \%)$ & $329.606(+40 \%)$ \\
\hline
\end{tabular}

(Rothman et al. 2007). Under the "Security First" scenario, production increases up to 226 million metric tons. Here, a slight decrease in per capita food availability can be observed.

Technological change is an important driving force in our analysis because it leads to changes in the magnitude of crop yields (productivity in metric tons per ha) and in irrigation project efficiency during the scenario period. Changes in crop yields are calculated by the IMPACT model as a function of future investments in the agricultural sector and other factors. Because future agricultural investments are assumed to be higher under the "Policy First" scenario than under the "Security First" scenario, increases in crop yields are also assumed to be larger under the first scenario. For instance, the average cereal yield increases by a factor of approximately 2.7 between 2000-2050 under the "Policy First" scenario, and by a factor of approximately two under the "Security First" scenario. Under the "Policy First" scenario, investments in new technologies lead to increases in irrigation project efficiency in all African regions, increasing from $55 \%$ in 2000 to $75 \%$ in 2050 . In contrast, the "Security First" scenario emphasizes security of water supply but with a low level of investments in the water sector and a low level of international trade in water-related technology. Hence, rapidly deteriorating infrastructure and poor management lead to a reduction in irrigation project efficiency under this scenario to an average level of $44 \%$ by 2050 . These absolute figures were determined in the scenario-analysis procedure of the GEO-4 assessment in a mutual effort including stakeholders and modelers.

\section{RESULTS}

\section{Continental-Level Simulation Results}

- Model experiment 1 (Baseline 2000): The calculated settlement area for 2000 covers only a relatively small fraction of the total continental land area $\left(122408 \mathrm{~km}^{2}\right)$. The total cropland area is calculated to be 2292000 $\mathrm{km}^{2}$ (about $7.8 \%$ of the total African land area) (Table 1). The WaterGAP calculations of current green water fluxes in Africa (based on climate data from 1971-2000, cropland area, and other assumptions from the year 2000) are $1085 \mathrm{~km}^{3} / \mathrm{yr}$ whereas blue water fluxes for irrigation are a magnitude lower $\left(179 \mathrm{~km}^{3} / \mathrm{yr}\right)$ (Table 2$)$.

- Model experiment 2 (Climate change 2050): In this model experiment, settlement and cropland area remain constant, but the climate input for WaterGAP is adjusted according to the GEO-4 scenarios (see the section entitled "Scenario Data"). Under these assumptions, the fluxes of green water at the continental level increase by $4 \%$ compared with the baseline for both scenarios. Although the extent of irrigated area remains constant, the irrigation water requirements for crops on this land (blue water fluxes) also show an increase of $4 \%$ because of decreasing precipitation, and/or increasing temperature in some areas. The calculated changes on the continental level are very similar for both scenarios because the differences in climatic changes under these scenarios up to 2050 are relatively small. 
Table 2. Continental green and blue water fluxes for Africa as calculated in model experiments 1 and 3.

\begin{tabular}{llll}
\hline \hline Fluxes $\left[\mathrm{km}^{3} / \mathrm{yr}\right]$ & 2000 & $\begin{array}{l}2050 \\
\text { Policy First }\end{array}$ & $\begin{array}{l}2050 \\
\text { Security First }\end{array}$ \\
\hline $\begin{array}{l}\text { Green water flux (evapotranspiration } \\
\text { from rainfed part of cropland) }\end{array}$ & 1085 & $1870(+72 \%)$ & $2040(+88 \%)$ \\
$\begin{array}{l}\text { Blue water flux (water withdrawals for } \\
\text { irrigation) }\end{array}$ & 179 & $194(+8 \%)$ & $330(+84 \%)$ \\
\hline
\end{tabular}

- Model experiment 3 (Climate change, landuse change, and technological change 2050): In this model experiment, we analyze the combined effect of climate change, land-use change, and changing irrigation project efficiency based on the respective scenario assumptions (see the section entitled "Scenario Data"). Tables 1 and 2 summarize the simulation results for both models.

Figure 1 shows the spatial pattern of cropland and settlement expansion from 2000-2050 for the two scenarios, as calculated by the LandSHIFT model. Settlement area nearly doubles under the "Policy First" scenario and increases by a factor of 2.6 under the "Security First scenario." Under the "Policy First" scenario, rainfed cropland area increase by $62 \%$, and irrigated area increases by $31 \%$ during this period. Under the "Security First" scenario, cropland expands by $69 \%$ and irrigated area expands by $40 \%$. The main reason for these differences is the assumption of an overall higher population growth under the "Security First" scenario, leading to a greater need for food-producing cropland. Another factor is that crop yields experience much stronger increases under the "Policy First" scenario, thereby reducing cropland requirements compared with those in the "Security First" scenario. Cropland expands at the expense of natural and seminatural biomes such as forests, shrubland, and savanna. Table 3 summarizes the area of different biome types that is converted to cropland during the simulation period.
The resulting spatial distribution of green and blue water fluxes calculated by WaterGAP is shown in Figs. 2 and 3. As a consequence of cropland expansion, green water fluxes increase by $72 \%$ ("Policy First") and $88 \%$ ("Security First"), respectively (Fig. 4). The largest green water fluxes in 2050 occur in regions that face a large increase in cropland area, together with changing climatic conditions that promote evapotranspiration. Examples are parts of western and eastern Africa (Fig. 2a). The largest blue water fluxes correspond to areas with high fractions of irrigated croplands in Africa (Fig. 3a). Under the "Policy First" scenario where very significant improvements in irrigation project efficiency are assumed (see the section entitled "Scenario Data"), irrigation water withdrawals increase by $8 \%$ from 20002050. In comparison, water withdrawals almost double (+84\%) in the "Security First" scenario because, here, irrigation project efficiency decreases due to the lack of financial investments made in the water sector (Fig. 5).

- Model experiment 4 (Natural vegetation green water fluxes): For this model experiment, we calculate the evapotranspiration from the natural vegetation covering the area that is converted to cropland from 2000-2050 (Fig. 1) under the respective climate-change scenarios. The calculated area conversions from each biome type to cropland are summarized in Table 3 . The green water flux from new cropland is about $12 \%-14 \%$ lower than the fluxes from the natural vegetation it has replaced (Fig. 4). 
Figure 1. Expansion of settlement area and cropland between 2000-2050 for the (a) "Policy First" and (b) "Security First" scenarios, as calculated by LandSHIFT.

\section{Land use changes}
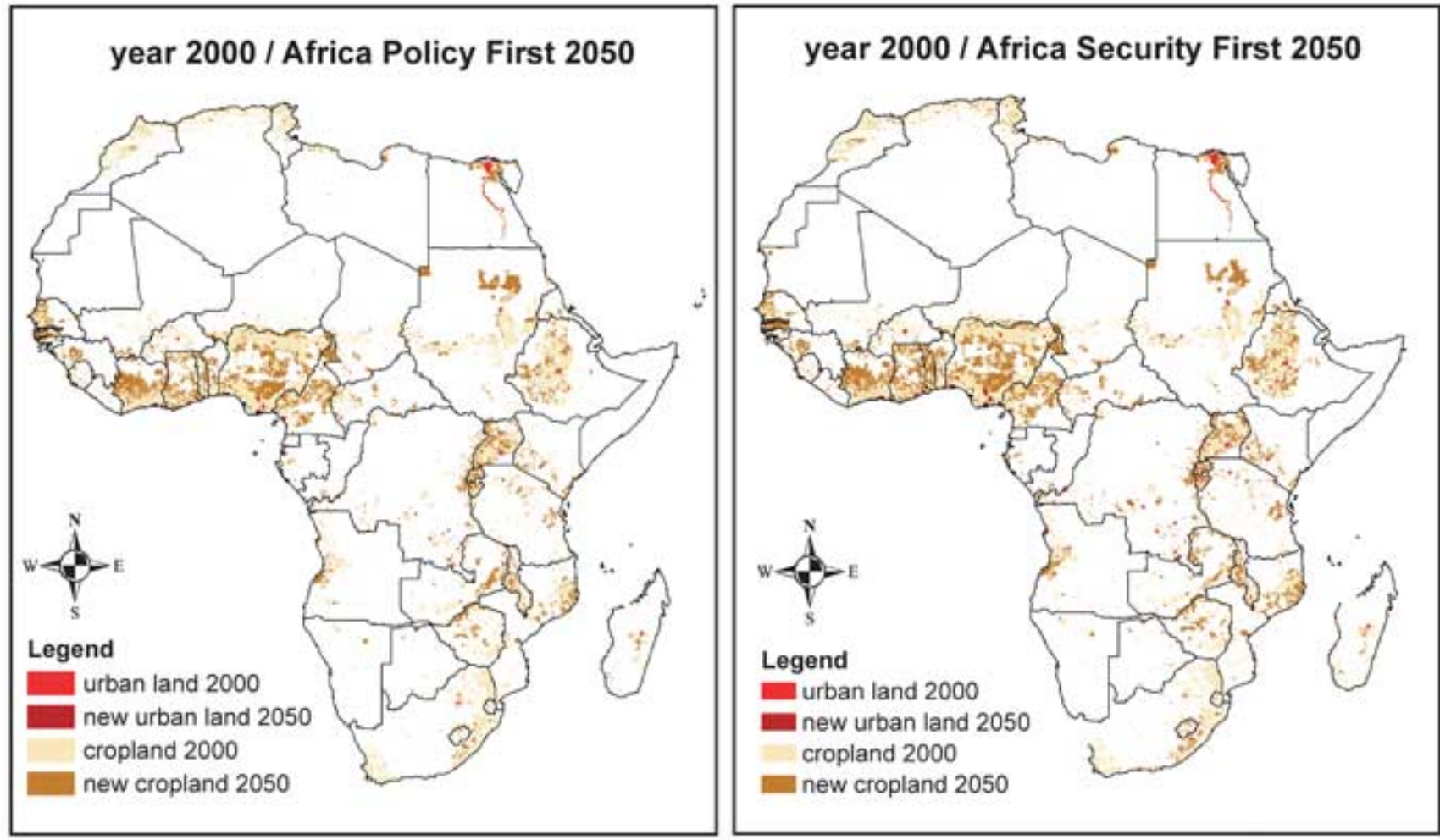

\section{Country-Level Simulation Results}

Of the 45 countries analyzed, 44 currently have a larger green water flux than blue water flux. Only Egypt's blue water flux exceeds its green water flux, due to its strong dependency on irrigated agriculture. With the exception of Algeria and the Comoros, all countries have increasing green water fluxes under both the "Policy First" and "Security First" scenarios up to 2050 (Fig. 6). Under the "Policy First" scenario, seven countries have a $25 \%$ or greater increase, nine countries have a $50 \%$ or greater increase, and 20 countries have a $75 \%$ or greater increase. Under the "Security First" scenario, six countries have a $25 \%$ or greater increase, six countries have a $50 \%$ or greater increase, and 25 countries have a $75 \%$ or greater increase. In 18 countries, the blue water flux decreases under the "Policy First" scenario when compared with current values. Under the "Security First" scenario, all blue water fluxes show significant increases (Fig. 7).

Nigeria shows the largest current and future green water fluxes, followed by Ethiopia and Cameroon. These countries are in this position because of their 
Table 3. Loss of biome area due to the expansion of cropland (biome types are derived from the GLCC land-cover data set).

\begin{tabular}{lll}
\hline \hline Area $\left[1000 \mathrm{~km}^{2}\right]$ & Policy First & Security First \\
\hline Shrubland & 24 & 38 \\
Savanna and grasslands & 648 & 762 \\
Tropical woodland & 280 & 329 \\
Forest & 154 & 229 \\
Barren & 144 & 157 \\
Total & 1251 & 1516 \\
\hline
\end{tabular}

large cropland areas and partly because of the moist climate over some of this cropland. In Nigeria, green water fluxes from cropland increase from $180 \mathrm{~km}^{3} /$ $\mathrm{yr}$ in 2000 up to $315 \mathrm{~km}^{3} / \mathrm{yr}$ in 2050 under "Policy First" and up to $325 \mathrm{~km}^{3} / \mathrm{yr}$ under "Security First." Blue water fluxes also show a significant increase, from $5 \mathrm{~km}^{3} / \mathrm{yr}$ in 2000 to $7 \mathrm{~km}^{3} / \mathrm{yr}$ in the year 2050 for the "Policy First" scenario and $15 \mathrm{~km}^{3} / \mathrm{yr}$ in the "Security First" scenario. In Morocco, a country that relies heavily on irrigated cropland, green water fluxes increase from $18 \mathrm{~km}^{3} / \mathrm{yr}$ to $21 \mathrm{~km}^{3} / \mathrm{yr}$, and 24 $\mathrm{km}^{3} / \mathrm{yr}$, respectively. Blue water fluxes decrease in the "Policy First" scenario from $14 \mathrm{~km}^{3} / \mathrm{yr}$ to 11 $\mathrm{km}^{3} / \mathrm{yr}$ but increase to $17 \mathrm{~km}^{3} / \mathrm{yr}$ in the "Security First" scenario. Zambia, on the other hand, relies almost completely on rainfed agriculture. Green water fluxes account for $24 \mathrm{~km}^{3} / \mathrm{yr} 2000$ and increase in 2050 to $51 \mathrm{~km}^{3} / \mathrm{yr}$ in the "Policy First" scenario, and $60 \mathrm{~km}^{3} / \mathrm{yr}$ in the "Security First" scenario.

\section{DISCUSSION AND CONCLUSIONS}

We have successfully combined LandSHIFT, a spatially explicit land-use change model, and WaterGAP, a hydrology model, to quantify the appropriation of fresh water by cropland in Africa under current conditions and for two internally consistent scenarios. To evaluate the predictive performance of our models, we compare the year 2000 simulation outcome for the most important variables in our study with different sources of statistical and literature data. These variables were the extent of cropland, the extent of irrigated land, green water fluxes from cropland, and blue water fluxes for irrigation purposes.

We find that the total cropland area for Africa computed by LandSHIFT (2 $\left.292000 \quad \mathrm{~km}^{2}\right)$ compares well to the statistical data of the AQUASTAT database (FAO 2003), where total cropland amounts to $2214010 \mathrm{~km}^{2}$ (the deviation is $3.5 \%$ ). The irrigated area is calculated to be 235 $428 \mathrm{~km}^{2}$, falling between the values given by the AQUASTAT database for the irrigation potential area of $467945 \mathrm{~km}^{2}$ and the actual irrigated area of $70265 \mathrm{~km}^{2}$. The blue water fluxes calculated by WaterGAP for $2000\left(179 \mathrm{~km}^{3} / \mathrm{yr}\right)$ also compare well to the $182 \mathrm{~km}^{3} / \mathrm{yr}$ of irrigation withdrawals given in AQUASTAT (FAO 2003). Although comparisons are difficult due the different underlying scenario assumptions, the simulated cropland expansion up to 2050 is in the same order of magnitude as that reported in the scenario analysis of the Millennium Ecosystem Assessment, which is between 50\%$60 \%$ for sub-Saharan Africa (Carpenter et al. 2005). In contrast, deforestation rates are lower. One explanation here is that our study does not consider the expansion of grazing land, which would put further stress on natural biomes.

To our knowledge, no other published studies currently exist that specifically focus on green water fluxes from cropland for the African continent. 
Figure 2. Green water fluxes from cropland in Africa for (a) the year 2000, (b) the GEO-4 "Policy First" scenario in 2050, and (c) the "Security First" scenario in 2050.

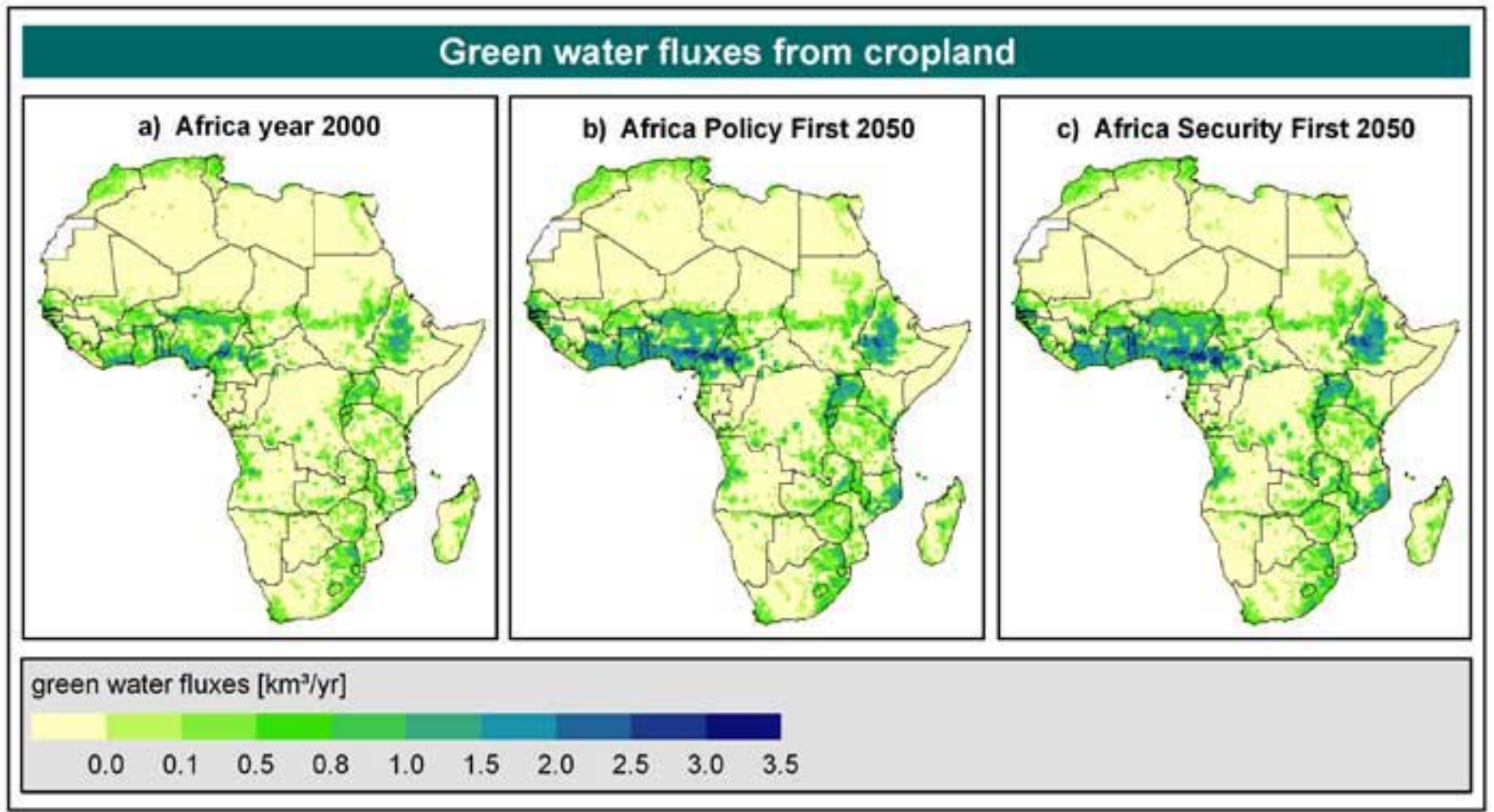

However, a recent study by Schuol et al. (2008) has examined total current green water fluxes on the African continent, and it obtains values of 14 449$15348 \mathrm{~km}^{3} / \mathrm{yr}$. This number compares well to the WaterGAP calculated value of $14670 \mathrm{~km}^{3} / \mathrm{yr}$ for the African continent.

For further evaluation, we compare values for total green water fluxes from a global model run by WaterGAP to other published global estimates. The global sum of evapotranspiration and interception as calculated by the WaterGAP model for 2000 equals $69000 \mathrm{~km}^{3} / \mathrm{yr}$. Rockström and Gordon (2001) calculated a global vapor flow of $71300 \mathrm{~km}^{3} /$ $\mathrm{yr}$, based on the spatial coverage of each biome and the annual evapotranspiration of each system. A recent study by Gerten et al. (2005) on green water fluxes with a global dynamic vegetation model resulted in a calculation of $63906 \mathrm{~km}^{3} / \mathrm{yr}$. Shiklomanov (1997) estimated global evapotranspiration in the magnitude of $72000 \mathrm{~km}^{3} / \mathrm{yr}$. As the results of the WaterGAP model fit very well into this range, we can conclude that our estimates of green water fluxes for cropland in Africa are also of a reasonable magnitude.

With regard to our methodology, the model experiments here have been conducted by softcoupling two disparate models. The strength of this approach is that the models can be used independently without significant changes to the respective internal structure and source code. Moreover, the simulation outcome can clearly be attributed to the respective model drivers. However, this approach can also lead to inconsistencies in how the different models handle different aspects of a specific topic. For example, the LandSHIFT and WaterGAP models deal with the spatial distribution and expansion of irrigated area differently. These disparities had to be reconciled for the model runs by spatially distributing the aggregated countrylevel changes of irrigated area calculated by LandSHIFT on the area equipped for irrigation. 
Figure 3. Blue water fluxes from cropland in Africa for (a) the year 2000, (b) the GEO-4 "Policy First" scenario in 2050, and (c) the "Security First" scenario in 2050.

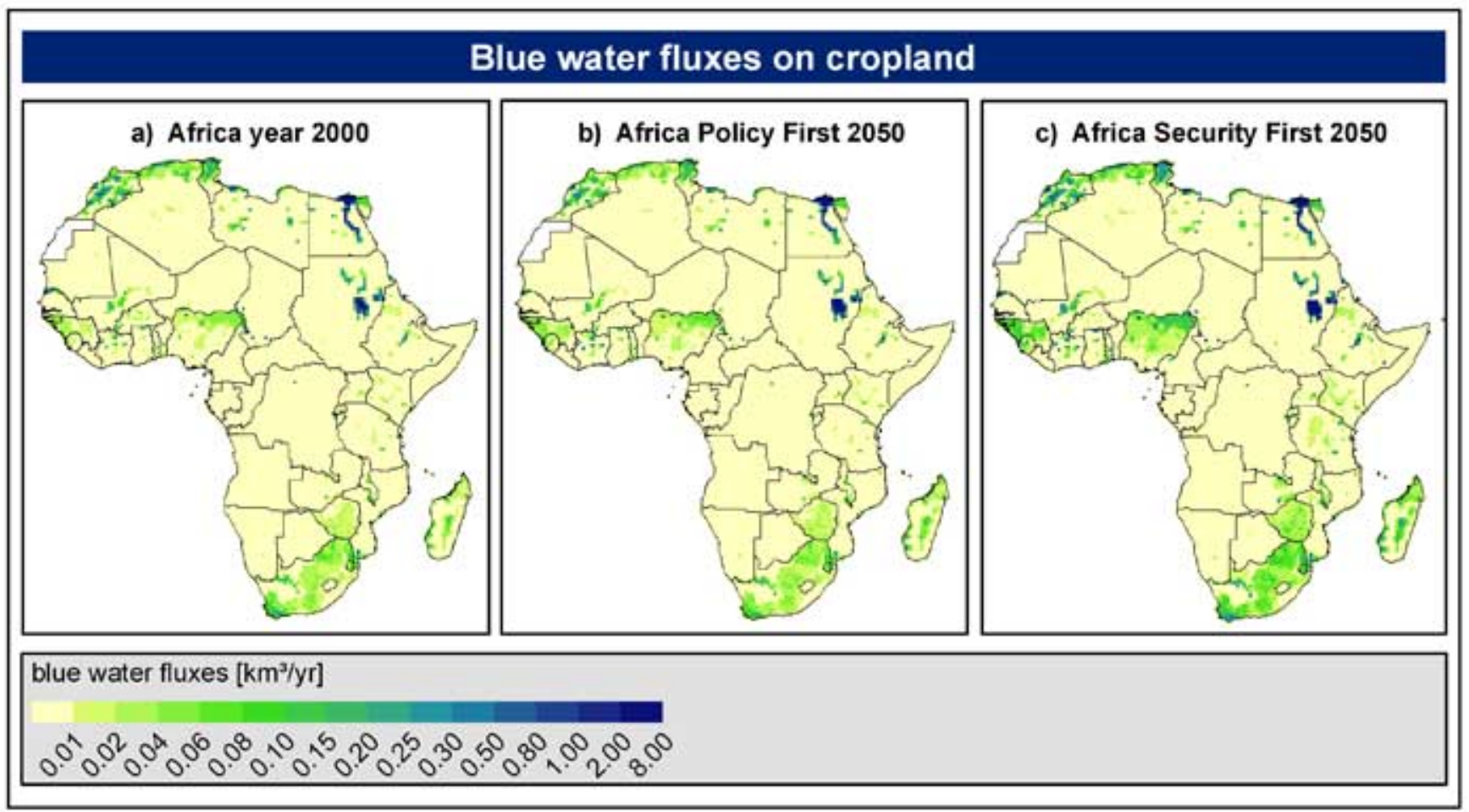

The sum of the model experiments indicates that human appropriation of freshwater for the cultivation of crops in Africa has a strong influence on the continental hydrological cycle, whichaccording to the calculated scenarios-is likely to further increase in the coming decades. Current green water fluxes from African cropland area are significant and add up to about half of the current continental runoff $\left(4500 \mathrm{~km}^{3} / \mathrm{yr}\right)$. Although the blue water fluxes of irrigation water withdrawals make up over $80 \%$ of current total African withdrawals (Alcamo et al. 2007), they are overshadowed by moisture fluxes from rainfed cropland. The water evaporated and transpired annually from Africa's rainfed cropland (green water) is 6.6 times greater than the volume of water used in liquid form to irrigate crops (the crop-related part of blue water). Furthermore, our model experiments suggest that the magnitude of green water fluxes will substantially increase over the coming years. Under the expansion of cropland described in the two scenarios we have presented, green water fluxes increase by $72 \%$ to $88 \%$. This is proportionately greater than the expansion of rainfed cropland area (62\% to $69 \%)$ and can be explained by the additional effect of warmer future temperatures stimulating plants' evapotranspirative processes. The size of green water fluxes in $2050\left(1870-2040 \mathrm{~km}^{3} / \mathrm{yr}\right)$ can be appreciated by comparing it to the current total continental runoff from the African continent $(4500$ $\left.\mathrm{km}^{3} / \mathrm{yr}\right)$. However, runoff in 2050 might be slightly larger $(+15 \%)$ according to the scenarios examined in this paper. Although blue water fluxes from irrigation will also increase in the future, the overall ratio between green and blue fluxes will remain about the same.

Nonetheless, the additional irrigation water withdrawals for newly converted land, a changing climate, and changes in efficiencies will compete with water demands from other sectors (e.g., the domestic and manufacturing sectors) that have to 
Figure 4. Continental green water fluxes from cropland. (For a description of the model experiments, see text.)

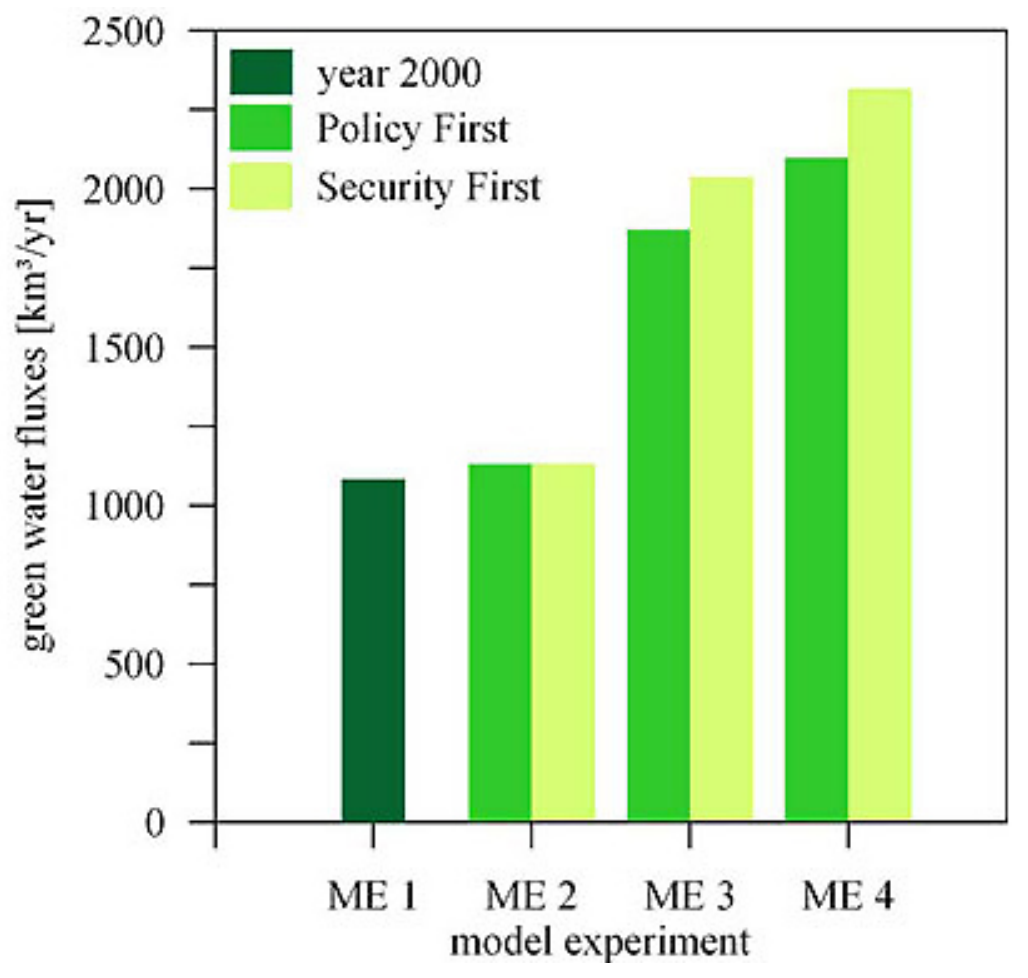

be met by the same water resource. In fact, total anthropogenic water uses increase by $36 \%$ under the "Policy First" scenario and by $170 \%$ under the "Security First" scenario (based on GEO-4 results and results from this study). Putting this number next to the actual quantity of water that is accessible for anthropogenic uses allows a first prediction of regions likely to suffer from water stress (Alcamo and Henrichs 2002, Alcamo et al. 2005, Alcamo et al. 2007). If the ratio of water withdrawn to water available exceeds 0.4 , the region is very likely to experience acute or chronic water shortages, where not enough water will be available to maintain environmental flows. The increased reuse of water resources leads to degraded water quality, limiting the functionality of ecosystems and further reuse. Although the situation for the Nile River improves under the "Policy First" scenario, under both the "Policy First" and "Security First" scenarios, the Senegal River, Limpopo River, White Nile River, and Shebelle River basins all fall into the category of severe water stress. The wetlands above Lake Victoria in particular will be endangered.

For both scenarios, the land-use simulations show that substantial areas of natural biomes are converted to cropland (Table 3 ) with consequences for both the land and water sides. On the one hand, the loss of natural biomes has negative impacts on biodiversity, leading to a trade-off among crop production and other ecosystem services (Carpenter et al. 2005). On the other hand, the impacts on the hydrological cycle also become obvious. In particular, the replacement of forests and tropical woodlands (that due to their greater leaf area and denser biomass tend to have higher evapotranspiration per unit area than cropland) leads to overall lower green water fluxes in our model results. This development, accompanied by the withdrawals and consumption of irrigation water, induces large 
Figure 5. Continental crop-related part of blue water fluxes (irrigation withdrawals). (For a description of the model experiments, see text.)

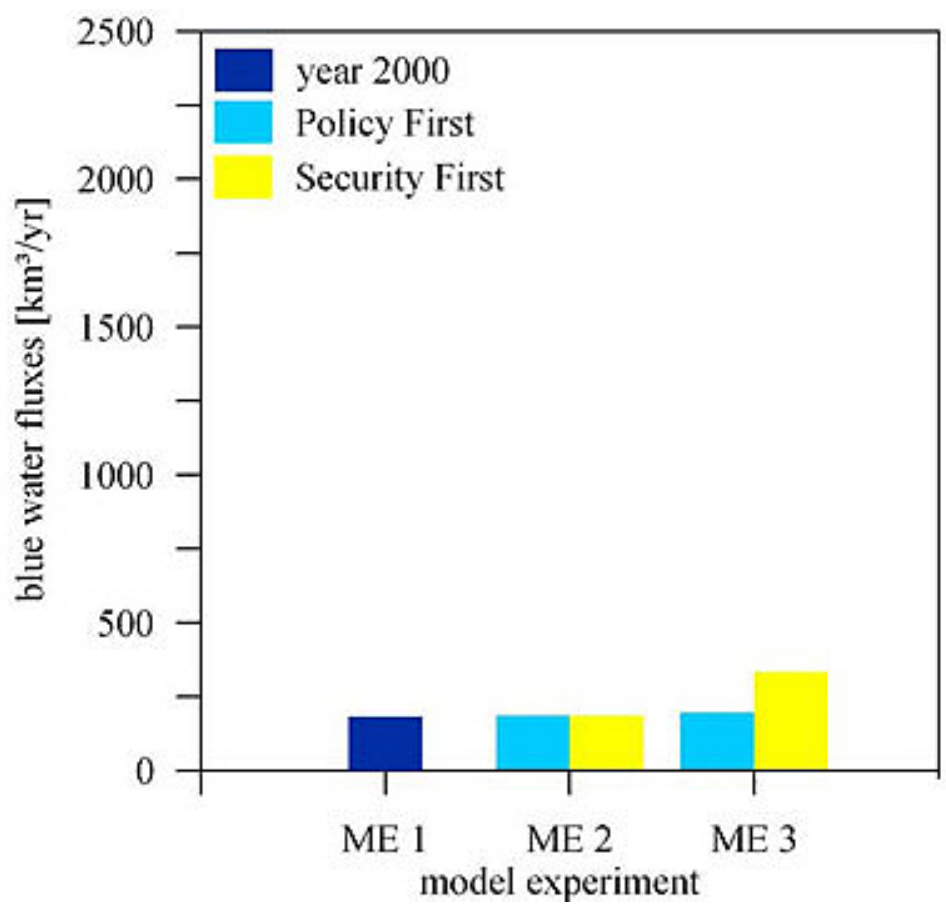

changes in local and regional water cycles, with potential effects on river discharge and even microclimatic conditions.

All of these results point to the important role that freshwater appropriated for crop production plays in the continental water cycle, both now and in the future. What implications does this have for agriculture? One conclusion, as Rockström and others have argued (Rockström 1999, Jewitt 2006, Rockström et al. 2007), is that it is worthwhile to improve not only irrigation water efficiency, but also, given its magnitude, the efficiency of water used by rainfed crops. In principle, this could allow the same amount of food to be produced with a reduced amount of water. All other factors remaining constant, more liquid water (surface and groundwater) would then remain to maintain freshwater ecosystems and natural flows, and satisfy anthropogenic water uses. This savings potential is reflected in our results by the difference in absolute fluxes under the "Policy First" and "Security First" scenarios. With assumptions of accelerated progress in improving crop yields and irrigation field efficiencies under the "Policy First" scenario, continental-scale green water fluxes increase by $72 \%$, compared to $88 \%$ under the "Security First" scenario, and blue water fluxes by $8 \%$ under the "Policy First" scenario compared with $84 \%$ under the "Security First" scenario.

However, all factors (and climate in particular) are subject to change during the course of the scenario period. In some countries, increasing precipitation related to global warming will compensate for increasing evapotranspiration, and therefore, water availability over a large area may remain the same. In other countries, decreasing precipitation will reduce the productivity of crops, thereby reducing evapotranspiration, and also reducing the overall amount of water available. In all cases, the continental-scale relationships between changing green water flux and the water cycle are and will remain complex, and merit careful analysis. 
Figure 6. Country-level green water fluxes from cropland for the year 2000, and for the "Policy First" and "Security First" scenarios for 2050.

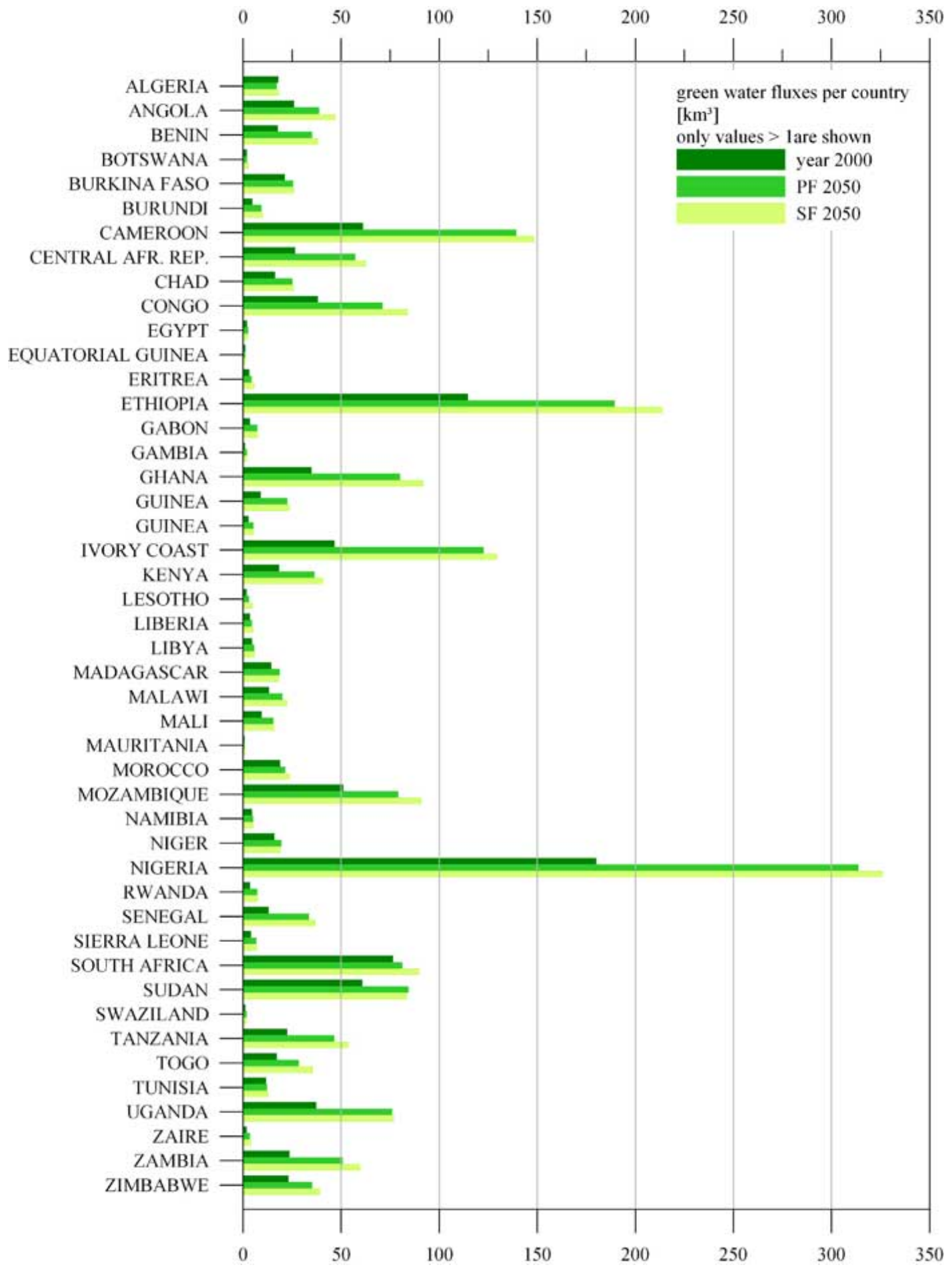


Figure 7. Country-level crop-related part of blue water fluxes (irrigation withdrawals) for the year 2000, and for the "Policy First" and "Security First" scenarios for 2050.

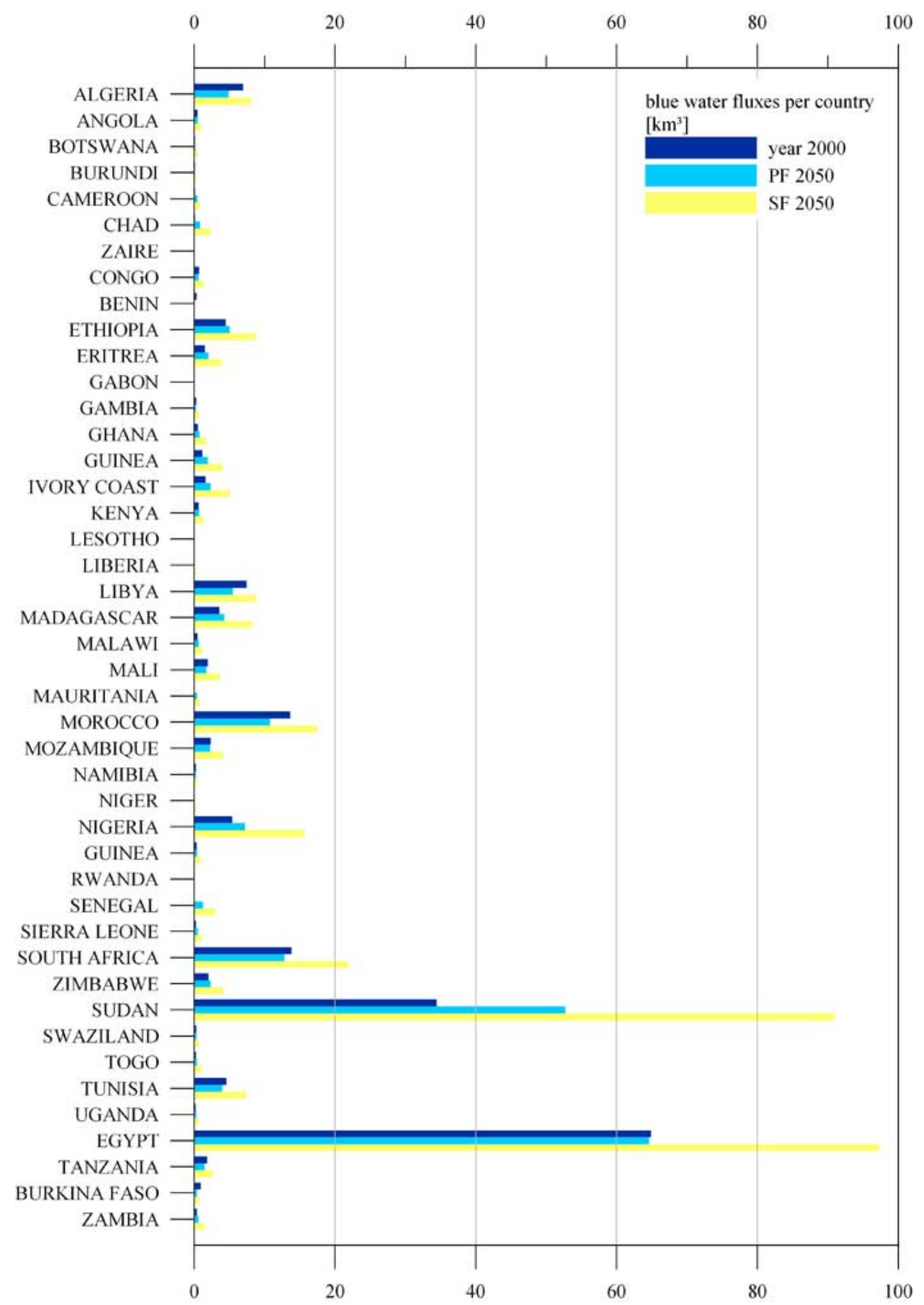


Responses to this article can be read online at: http://www.ecologyandsociety.org/voll4/iss2/art25/ responses/

\section{Acknowledgments:}

This work was carried out in the framework of an international assessment of global blue and green water fluxes under the Global Water Assessment Project of the Earth System Science Partnership. The authors wish to thank the reviewers for their valuable comments. One of the authors (Alcamo) acknowledges the research support of the German Research Foundation (DFG) through research grant GZ: AL 606/4-1, and the assistance of the University of Stellenbosch, South Africa, Department of Geology, Geography and Environmental Sciences (Department Chair, Prof. J. D. Clemens).

\section{LITERATURE CITED}

Alcamo, J., and T. Henrichs. 2002. Critical regions: a model-based estimation of world water resources sensitive to global changes. Aquatic Sciences-Research Across Boundaries 64:352362.

Alcamo, J. M. 2008. The practice of environmental scenario analysis (developments in integrated environmental assessment). Environmental Futures, Volume 2. Elsevier, New York, New York, USA.

Alcamo, J. M., P. Döll, T. Henrichs, F. Kaspar, B. Lehner, T. Rösch, and S. Siebert. 2003. Development and testing of the WaterGAP 2 global model of water use and availability. Hydrological Sciences 48:317-337.

Alcamo, J. M., M. Flörke, and M. Märker. 2007. Future long-term changes in global water resources driven by socio-economic and climatic changes. Hydrological Sciences Journal/Journal des Sciences Hydrologiques 52:247-275.

Alcamo, J. M., and R. Schaldach. 2006. LandShift: global modelling to assess land use change. Pages 223-230 in K. Tochtermann, and A. Scharl, editors. EnviroInfo 2006: Managing
Environmental Knowledge. Proceedings of the 20th International Conference on Informatics for Environmental Protection. Shaker, Graz, Austria.

Alcamo, J. M., D. van Vuuren, C. Ringler, W. Cramer, T. Masui, J. Alder, and K. Schulze. 2005. Changes in nature's balance sheet: model-based estimates of future worldwide ecosystem services. Ecology and Society 10:27. [online] URL: www.ec ologyandsociety.org/vol10/iss2/art19/

Bouwman, A. F., T. Kram, and K. Klein Goldewijk. 2006. Integrated modelling of global environmental change: an overview of IMAGE 2.4. Netherlands Environmental Assessment Agency, Bilthoven, Netherlands.

Carpenter, S. R., P. L. Pingali, E. M. Bennett, and M.B.Zurek, editors. 2005. Ecosystems and human well-being scenarios. Findings of the Scenarios Working Group, Millennium Ecosystem Assessment (MEA) Series. Island Press, Washington, D.C., USA.

Center for Earth Science Information Network (CIESIN). 2004. Global rural-urban mapping project (GRUMP), alpha version: population density grids. Socioeconomic Data and Applications Center (SEDAC), Columbia University, New York, USA. [online] URL: http://beta.sedac.ciesin.columbia. edu/gpw/.

Döll, P., F. Kaspar, and B. Lehner. 2003. A global hydrological model for deriving water availability indicators: model tuning and validation. Journal of Hydrology 270:105-134.

Döll, P., and B. Lehner. 2002. Validation of a new global 30-min drainage direction map. Journal of Hydrology 258:214-231.

Döll, P., and S. Siebert. 2000. A digital global map of irrigated areas. Irrigation and Drainage 49:5566.

Döll, P., and S. Siebert. 2002. Global modeling of irrigation water requirements. Water Resources Research 38:10.

Douglas, E. M., K. Sebastian, C. J. Vörösmarty, S. Wood, and K. M. Chomitz. 2005. The role of tropical forests in supporting biodiversity and 
hydrological integrity: a synoptic overview. Policy Research Working Paper Series 3635. The World Bank, Washington, D.C., USA.

Eastman, J. R., W. Jin, P. Kyem, and J. Toledano. 1995. Raster procedures for multiobjective land-use planning. Photogrammetric Engineering and Remote Sensing 61:539-547.

Falkenmark, M. 1995. Land-water linkages: a synopsis. Pages 15-16 in T. H. Mather, editor. Land and water integration and river basin management. Proceedings of an FAO Informal Workshop. Food and Agriculture Organization (FAO), Rome, Italy.

Food and Agriculture Organization(FAO). 1997. Irrigation potential in Africa: a basin approach. Land and Water Bulletin 4. Rome, Italy.

FAO. 2003. AQUASTAT online database. Rome, Italy. [online] URL: http://www.fao.org/nr/water/a quastat/dbases/index.stm.

FAO. 2008. FAO statistical database. Rome, Italy. [online] URL: http://faostat.fao.org/.

Gerten, D., H. Hoff, A. Bondeau, W. Lucht, P. Smith, and S.Zaehle. 2005. Contemporary "green" water flows: simulations with a dynamic global vegetation and water balance model. Physics and Chemistry of the Earth 30:334-338.

Global Runoff Data Centre (GRDC). 2004. Long term mean monthly discharges and annual characteristics of selected GRDC stations. Koblenz, Germany.

Heistermann, M., C. Müller, and K. Ronneberger. 2006. Land insight? Achievements, deficits and potentials of continental to global scale land-use modeling. Agriculture, Ecosystems and Environment 114:141-158.

Hughes, B., and E. Hillebrand. 2006. Exploring and shaping international futures. Paradigm, Boulder, Colorado, USA.

Jewitt, G. 2006. Integrating blue and green water flows for water resources management and planning. Physics and Chemistry of the Earth 31:753-762.

Loveland, T. R., B. C. Reed, J. F. Brown, D. O. Ohlen, Z. Zhu, L. Yang, and J. W. Merchant. 2000. Development of a global land cover characteristics database and IGBP DISCover from 1-km AVHRR data. International Journal of Remote Sensing 21:1303-1330.

Mitchell, T. D., and P. D. Jones. 2005. An improved method of constructing a database of monthly climate observations and associated highresolution grids. International Journal of Climatology 25:693-712.

National Imagery and MappingAgency (NIMA). 1997. Vector map level O (VMAPO). [online] URL: http://earth-info.nga.mil/publications/vmap0.html

Parton, W. J., M. Hartman, D. Ojima, and D. Schimel. 1998. DAYCENT and its land surface submodel: description and testing. Global and Planetary Change 19:35-48.

Postel, S. L., G. C. Daily, and P. R. Ehrlich. 1996. Human appropriation of renewable fresh water. Science 271:785-788.

Priestley, C. H. B., and R. J. Taylor. 1972. On the assessment of surface heat flux and evaporation using large scale parameters. Monthly Weather Review 100:81-92.

Rockström, J. 1999. On-farm green water estimates as a tool for increased food production in water-scarce regions. Physics and Chemistry of the Earth-Part B: Hydrology Oceans and Atmosphere 24:375-383.

Rockström, J., M. Falkenmark, L. Karlberg, H. Hoff, S. Rost, and D. Gerten. 2009. Future water availability for global food production: the potential of green water for increasing resilience to global change. Water Resources Research 45:W00A12.

Rockström, J., and L. Gordon. 2001. Assessment of green water flows to sustain major biomes of the world: implications for future ecohydrological landscape management. Physics and Chemistry of the Earth-Part B: Hydrology Oceans and Atmosphere 26:843-851.

Rockström, J., L. Gordon, C. Folke, M. Falkenmark, and M. Engwall. 1999. Linkages among water vapor flows, food production, and terrestrial ecosystem services. Conservation Ecology 3(2):5. [online] URL: http://www.consecol. org/vol3/iss2/art5/ 
Rockström, J., M. Lannerstad, and M. Falkenmark. 2007. Assessing the water challenge of a new green revolution in developing countries. Proceedings of the National Academy of Sciences of the United States of America 104:6253-6260.

Rosegrant, M. W., S. Meijer, and S. A. Cline. 2002. International model for policy analysis of agricultural commodities and trade (IMPACT): model description. International Food Policy Research Institute, Washington, D.C., USA.

Rothman, D., J. Agard, and J. Alcamo. 2007. The future today. Pages 395-454 in Global Environmental Outlook-4 (GEO-4). United Nations Environment Programme (UNEP). EarthPrint, Stevenage, Hertfordshire, UK.

Scanlon, B. R., I. Jolly, M. Sophocleous, and L. Zhang. 2007. Global impacts of conversions from natural to agricultural ecosystems on water resources: quantity versus quality. Water Resources Research 43:W03437.

Schaldach, R., and J. Alcamo. 2006. Coupled simulation of regional land use change and soil carbon sequestration: a case study for the state of Hesse in Germany. Environmental Modelling and Software 21:1430-1446.

Schaldach, R., J. Alcamo, and M. Heistermann. 2006. The multiplescale land use change model LandShift: a scenario analysis of land use change and environmental consequences in Africa. In A. Voinov, A. J. Jakeman, and A. E. Rizzoli, editors. Proceedings of the iEMSs Third Biennial Meeting: Summit on Environmental Modelling and Software. International Environmental Modelling and Software Society, Burlington, Vermont, USA.

Schaldach, R., J. Priess, and J. Alcamo. 2009. Simulating the impact of bio-fuel development on country-wide land-use change in India. Biomass and Bioenergy, in press.

Schuol, J., K. C. Abbaspour, H. Yang, R. Srinivasan, and A. J. B. Zehnder. 2008. Modeling blue and green water availability in Africa. Water Resources Research 44:W07406.

Shiklomanov, I. A. 1997. Comprehensive assessment of the freshwater resources and water availability in the world: assessment of water resources and water availability in the world. World Meteorological Organization, Geneva, Switzerland.
Solomon, S., D. Qin, M. Manning, Z. Chen, M. Marquis, K. B. Averyt, M. Tignor, and H. L. Miller, editors. 2007. Climate change 2007: the physical science basis. Contribution of Working Group I to the Fourth Assessment Report of the Intergovernmental Panel on Climate Change. Cambridge University Press, Cambridge, UK.

Stehfest, E., M. Heistermann, J. A. Priess, D. S. Ojima, and J. Alcamo. 2007. Simulation of global crop production with the ecosystem model DAYCENT. Ecological Modelling 209:203-219.

United Nations Environment Programme (UNEP). 2002. Global environment outlook-3: past, present and future perspectives (GEO-3). Earthscan, London, UK.

UNEP. 2007. Global environment outlook: environment for development (GEO-4). Progress Press, Valetta, Malta.

United States Geological Survey (USGS). 1998. HYDROlk: Elevation derivative database. EROS Data Center, Sioux Falls, South Dakota, USA.

World Database on Protected Areas (WPDA) Consortium. 2004. World Database on Protected Areas. [online] URL: http://www.wdpa.org/. 